\title{
BENEATH THE SURFACE
}


THEORY IN FORMS A series edited by Nancy Rose Hunt and Achille Mbembe 


\section{BENEATH THE SURFACE \\ A Transnational History of Skin Lighteners}

LYNN M. THOMAS

Duke University Press Durham and London 2020 
(C) 2020 DUKE UNIVERSITY PRESS. All rights reserved Printed in the United States of America on acid-free paper $\infty$ Designed by Courtney Leigh Baker Typeset in Huronia Pro and Knockout by Westchester Publishing Services

\section{Library of Congress Cataloging-in-Publication Data}

Names: Thomas, Lynn M., [date] author.

Title: Beneath the surface : a transnational history of skin lighteners / Lynn M. Thomas.

Other titles: Theory in forms.

Description: Durham : Duke University Press, 2019. | Series: Theory in forms | Includes bibliographical references and index.

Identifiers: LCCN 2019013462 (print)

LCCN 2019980443 (ebook)

ISBN 9781478005384 (hardcover)

ISBN 9781478006428 (paperback)

ISBN 9781478007050 (ebook)

Subjects: LCSH: Colorism-South Africa. | Human skin color-

Social aspects-South Africa. | Human skin color-Economic aspects-South Africa. | Racism-South Africa. | Race relations.

Classification: LCC GN197 .S524 2019 (print) | LCC GN197 (ebook) | DDC 612.7/927-dc23

LC record available at https://lccn.loc.gov/2019013462

LC ebook record available at https://lccn.loc.gov/2019980443

COVER ART: Stills from the short film Yellow Fever, 2012. (C) Ng'endo Mukii.

Duke University Press gratefully acknowledges the Department of History and the College of Arts and Sciences at the University of Washington, which provided funds toward the publication of this book. 
FOR MICHAEL AND IN MEMORY OF STEPHANIE 
This page intentionally left blank 